\title{
Chemical profile of the polar extract of Paepalanthus microphyllus (Guill.) Kunth (Eriocaulaceae)
}

\author{
Lourdes Campaner dos Santos ${ }^{1 *}$, Miriam Sannomiya ${ }^{1}$, Sonia Piacente ${ }^{2}$, Cosimo Pìzza ${ }^{2}$, \\ Paulo Takeo Sano ${ }^{3}$, Wagner Vilegas ${ }^{1}$
}

'Instituto de Química, Universidade Estadual Paulista "Júlio de Mesquita Filho", ${ }^{2}$ Dipartimento di Scienze Farmaceutiche, Università degli Studi di Salerno, ${ }^{3}$ Instituto de Biociências, Universidade de São Paulo

*Correspondence

L. C. Santos

Instituto de Química de Araraquara UNESP

Rua Francisco Degni, s/n

Bairro Quitandinha

14800-900 - Araraquara - SP - Brasil

E-mail: loursant@iq.unesp.br
From the ethanolic extract of the capitulae of Paepalanthus microphyllus, one caffeic acid derivative (1) was isolated. The structure of the compound was characterized by spectroscopic methods, mainly $1 D$ and 2D NMR experiments, as well as ESMS spectrometry. In addition, three flavonoids of taxonomic relevance were isolated and identified by comparison to literature data.
Uniterms:

- Caffeic acid derivative

- Eriocaulaceae

- Paepalanthus

\section{INTRODUCTION}

The Eriocaulaceae family encompasses around 1200 species, many of which are ornamental and endemic of Brazil (Giulietti et al., 2000). However, few of these plants have been chemically studied. Among the investigated species, those belonging to Paepalanthus genus are known for the production naphthopyranone and flavonoid glycosides (Vilegas et al., 1998; Vilegas et al., 1999a,b; Santos et al., 2001a,b; Piacente et al., 2001). The isolated compounds have shown a number of biological activities, like mutageniticity (Tavares et al., 1999; Coelho et al., 2000; Moreira et al., 2000).

This work deals with the chemical investigation of $P$. microphyllus Giull. Kunth., that belongs to subgenus Paepalocephalus section Eriocaulopsis, that grows wild at Serra do Cipó, Espinhaço Chain, Minas Gerais State, Brazil.

\section{MATERIALS AND METHODS}

\section{Plant material}

Capitula of P. microphyllus (Guill.) Kunth.
(Eriocaulaceae) were collected in February 1997, at Serra do Cipó, in Espinhaço Chain, Minas Gerais State, Brazil. The specimen were determined by Prof. Paulo Takeo Sano from Instituto de Biociências, USP, São Paulo. A voucher specimen (CFCR 5610) has been deposited at the Herbarium SPF (Departamento de Botânica, Instituto de Biociências, Universidade de São Paulo, Brazil).

\section{General experimental procedures}

Capitulae of Paepalanthus microphyllus (300 g) were powdered and extracted successively with $n$-hexane, methylene choride an EtOH (1 week each). Solvents were evaporated under vacuum. The EtOH-extract $(2.0 \mathrm{~g})$ was chromatographed on a Sephadex LH-20 collumn $(100 \times 5 \mathrm{~cm})$, with $\mathrm{MeOH}$ as eluent. Fractions $(8 \mathrm{~mL})$ were collected and checked by TLC [Si gel plates, BAW ( $n$ $\mathrm{BuOH} / \mathrm{AcOH} / \mathrm{H}_{2} \mathrm{O}$ 12:3:5, v/v/v)]. Fractions were further purified by HPLC on a Waters 590 system equipped with a Waters R401 refractive index detector and with a Waters ( $m$-Bondapak RP-18) column (30 cm x $7.6 \mathrm{~mm}$ i.d) using $\mathrm{MeOH}-\mathrm{H}_{2} \mathrm{O}(1: 1, \mathrm{v} / \mathrm{v})$ as eluent equiped with a Photo Diode-Array Detector set at $254 \mathrm{~nm}$. We obtained the pure compounds 1,3-di-E-caffeoylglycerol 1, and the flavonoids 
$3^{\prime}, 4^{\prime}, 5,6,7,8$-hexahydroxyflavone $2,3^{\prime}, 4^{\prime}, 5,6,7$ pentahydroxyflavone 3 and 3',4',5,6-tetra-hydroxy-7-O- $\beta$ D-glucopyranosilflavone, 4 (Figure 1). NMR spectra in $\mathrm{CD}_{3} \mathrm{OD}$ were obtained using a Bruker DRX-600 spectrometer, operating at $599.19 \mathrm{MHz}$ for ${ }^{1} \mathrm{H}$ and 150.86 $\mathrm{MHz}$ for ${ }^{13} \mathrm{C}$. 2D experiments: ${ }^{1} \mathrm{H}-{ }^{1} \mathrm{H}-\mathrm{COSY}$ (Chemical shift correlation spectroscopy), inverse-detected ${ }^{1} \mathrm{H}-{ }^{13} \mathrm{C}$ HSQC (heteronuclear single quantum coherence), HMBC (heteronuclear multiple bond connectivity). ESMS were performed in a Fisons Platform spectrometer in the positive mode $(70 \mathrm{~V})$. The sample were dissolved in $\mathrm{MeOH}$ and injected directly.

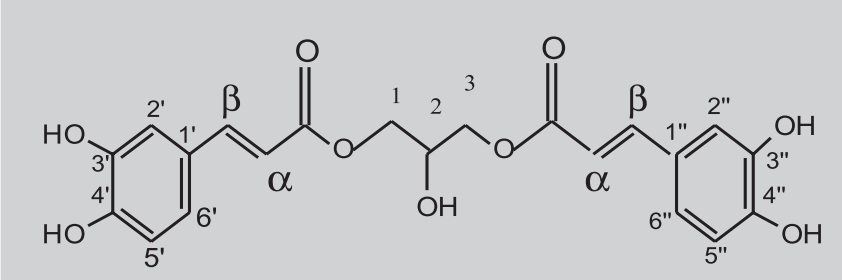

1
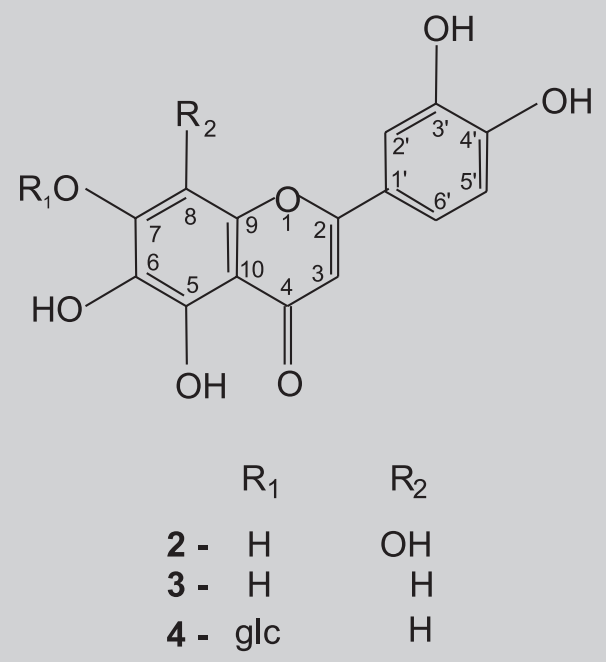

FIGURE 1 - Compounds from P. microphyllus.

\section{RESULTS AND DISCUSSION}

Compound 1 was colourless and amorphous. The IR spectra showed hydroxy groups $\left(3400 \mathrm{~cm}^{-1}\right)$, an $\alpha, \beta$ unsaturated ester $\left(v_{\mathrm{C}=\mathrm{O}} 1700 \mathrm{~cm}^{-1}\right)$, an alkene conjugated with an aromatic ring $\left(\mathrm{v}_{\mathrm{C}=\mathrm{C}} 1620 \mathrm{~cm}^{-1}\right)$, and an aromatic ring $\left(1590,1505 \mathrm{~cm}^{-1}\right)$. The ESMS (70V, positive mode) gave the quasi-molecular ion $[\mathrm{M}+\mathrm{H}]^{+}$at $m / z 417$, corresponding to the molecular formula $\mathrm{C}_{21} \mathrm{H}_{20} \mathrm{O}_{9}$, and fragment at $\mathrm{m} / \mathrm{z} 180$, corresponding to the formula protonated $\left[\mathrm{C}_{9} \mathrm{H}_{7} \mathrm{O}_{4}+\mathrm{H}\right]^{+}$, and $\mathrm{m} / z 238$, corresponding to the fragment $\left[\mathrm{C}_{12} \mathrm{H}_{7} \mathrm{O}_{13}+\mathrm{H}\right]^{+}$. Loss of the two units of the caffeoyl moiety of 1 led to the glycerol unit observed at $m /$ $z 60$.

In the ${ }^{1} \mathrm{H}$ NMR spectrum, the signals for the primary alcoholic functions and the secondary alcoholic function of a glycerol unit were evident at $\delta 4.29(4 \mathrm{H}, \mathrm{m})$ for the two $\mathrm{OCH}_{2}$ groups of glycerol and the signal of an $\mathrm{OCH}$ group at $\delta 4.16(1 \mathrm{H}, \mathrm{m})$. Also evident were two doublets typical of a trans double bond at $\delta 6.32(2 \mathrm{H}, \mathrm{d}, J=16.0 \mathrm{~Hz})$ and $7.57(2 \mathrm{H}, \mathrm{d}, J=16.0 \mathrm{~Hz})$ and signals at $\delta 6.56(2 \mathrm{H}, \mathrm{dd}, J$ $=1.5$ and $8.0 \mathrm{~Hz}), 6.77(2 \mathrm{H}, \mathrm{d}, J=8.0 \mathrm{~Hz})$ and $7.07(2 \mathrm{H}$, $\mathrm{d}, J=1.5 \mathrm{~Hz}$ ). The above signals suggested the occurrence of two caffeoyl moieties (Birkofer et al., 1968) which should be linked to $\mathrm{C}-1$ and $\mathrm{C}-3$ of the glycerol unit in a symmetrical position in agreement with the ${ }^{1} \mathrm{H} N M R$ and ${ }^{13} \mathrm{C}$ NMR signals. The HMBC spectrum showed connectivities for $\mathrm{H}-1$ and $\mathrm{H}-3$ of the glycerol unit $(\delta 4.29)$ and $(\mathrm{C}=\mathrm{O})$ of the caffeoyl units $(\delta 169.0)$. Thus, $\mathbf{1}$ was identified as 1,3-O-di-E-caffeoylglycerol.

TABLE I - ${ }^{1} \mathrm{H}$ and ${ }^{13} \mathrm{C}$ data of $1,3-O$-di- $E$-caffeoylglycerol (1) in $600 \mathrm{MHz}$ ( $J$ in HZ; attribute values accordingly to HSQC, HMBC experiments)

\begin{tabular}{ccc}
\hline Position & ${ }^{13} \mathbf{C}$ & ${ }^{\mathbf{1}} \mathbf{H}$ \\
\hline 1 & 66.0 & $4.29 \mathrm{~m}$ \\
2 & 68.3 & $4.16 \mathrm{~m}$ \\
3 & 66.0 & $4.29 \mathrm{~m}$ \\
$1^{\prime}, 1^{\prime \prime}$ & 127.4 & - \\
$2^{\prime}, 2^{\prime \prime}$ & 115.1 & $7.07 \mathrm{~d}(1.5)$ \\
$3^{\prime}, 3^{\prime \prime}$ & 147.8 & - \\
$4^{\prime}, 4^{\prime}$ & 149.5 & - \\
$5^{\prime}, 5^{\prime}$ & 116.6 & $6.77 \mathrm{~d}(8.0)$ \\
$6^{\prime}, 6^{\prime}$ & 122.9 & $6.56 \mathrm{dd}(1.5,8.0)$ \\
$\alpha$ & 114.6 & $6.32 \mathrm{~d}(16.0)$ \\
$\beta$ & 147.2 & $7.57 \mathrm{~d}(16.0)$ \\
$\mathrm{C}=\mathrm{O}$ & 169.0 & - \\
\hline
\end{tabular}

The structures of the flavonoids 2-4 compounds were unambiguously determined by means of spectroscopic methods (IR, ESMS, ${ }^{1} \mathrm{H},{ }^{13} \mathrm{C}$ and 2D NMR experiments COSY, HSQC, HMBC) and compared to those previously reported (Agrawal, 1989; Harborne, Mabry, 1982; Harborne, 1998).

Caffeic acid and other hydroxycinnamic derivatives are of major importance for the protection of plants against herbivores and pathogens (Bazzalo et al., 1985). They also have important biological activities. Braca et al. (2003) reported the antioxidant and free radical scavenging activities of caffeoyl acid derivatives from different Aconitum species. Baset et al. (1996) reported the in vitro 
hepatoprotective activity of four di-O-caffeoyl quinic acid derivatives from propolis. Kwon et al. (2000) reported the inhibitory activity against human immunodeficiency virus1 presented by the caffeoyl quinic acid isolated from the aerial parts of Aster scaber Thunb. (Asteraceae).

Natural bitter phenolic glycerol derivatives have been isolated from a number of Lilium species (Liliaceae) as well as from plants of the Gramineae, Bromeliaceae and Salicaceae families (Shimomura et al, 1986; Shimomura et al., 1989).

\section{CONCLUSION}

The presence of compound $\mathbf{1}$ in P. microphyllus is the first report of a natural phenolic glyceride in Eriocaulaceae. Since it is reported the bitter taste of this kind of substance, this could explain the fact that species from this family are hardly attacked by insect in the region where they occur. Further studies are in progress to check this possibility.

\section{ACKNOWLEDGEMENTS}

We thank FUNDUNESP and FAPESP for financial aid, for FAPESP to a fellowship to M.S. and to CNPq for a grant to W.V.

\section{RESUMO}

\section{Perfil químico do extrato polar de Paepalanthus microphyllus(Guill.) Kunth (Eriocaulaceae)}

Do extrato etanólico dos capitulos de Paepalanthus microphyllus, isolou-se um derivado do ácido cafeico (1). Sua estrutura foi caracterizada por métodos espectroscópicos (RMN mono e bi-dimensionais) e por espetrometria de massas Electrospray. Foram, também, isolados outros três flavonóides (2-4) de interesse taxonômico, os quais foram identificados por métodos espectroscópicos e comparados com dados da literatura.

UNITERMOS: Derivado do ácido cafeico. Eriocaulaceae. Paepalanthus.

\section{REFERENCES}

AGRAWAL, P. K. Carbon 13 NMR of flavonoids. Amsterdam: Elsevier, 1989, 564 p.
BASET, P.; MATSUSHIGE, K.; HASE, K.; KADOTA, S.; NAMBA, T. Four di-O-caffeoyl quinic acid derivatives from propolis. Potente hepatoprotective activity in experimental liver injury models. Biol. Pharm. Bull., v. 19, n.11, p. 1479-1484, 1996.

BAZZALO, M. E.; HEBER, E. M.; MARTINEZ, M. A.; DEL PERO; CASO, O. H. Phenolic compounds in stems of sunflower plants inoculated with sclerotiniasclerotiorum and their inhibitory effects on the fungus. Phytopathol. Z., v. 112, p. 322-332, 1985.

BIRKOFER, L.; KAISER, C.; THOMAS, U. Acteoside and neoacteoside sugar esters from Syringa vulgaris (L). $Z$. Naturforsch. PT B. B., v. 23, p. 1051-1058, 1968.

BRACA, A.; POLITI, M.; SANOGO, R.; SANOU, H.; MORELLI, I.; PIZZA, C.; DE TOMMASI, N. Chemical composition and antioxidant activity of phenolic compounds from wild and cultivated Sclerocarya birrea (Anacardiaceae) leaves. J. Agric. Food Chem., v. 51, p. 6689-6695, 2003.

COELHO, R. G.; VILEGAS, W.; DEVIENE, F. K.; RADDI, M. S. G. A new cytotoxic naphthopyrone dimer from Paepalanthus bomeliodes. Fitoterapia, v. 71, p. 497-500, 2000.

GIULIETTI, A. M.; SCATENA, V. L.; SANO, P. T.; PARRA, L. R.; QUEIROZ, L. P.; HARLEY, R. M.; MENEZES, N. L.; YSEPON, A. M. B.; SALATINO, A.; SALATINO, M. L.; VILEGAS, W.; SANTOS, L. C.; RICCI, V. C.; BONFIM, M. C. P.; MIRANDA, E. B. Multidisciplinary on neotropical Eriocaulaceae and Evolution. In: WILSON, K. L. MORRISON, D. A., Eds. Monocots: systematic and evolution. Melbourne: CISRO Publishing, 2000. v. 1, p. 580-589.

HARBORNE, J. B. Phytochemical Methods: a guide to modern techniques of plant analysis. 3. ed. London: Chapman and Hall, 1998. 302 p.

HARBORNE, J. B.; MABRY, T. J. Flavone and flavonol glyosides. In: HARBORNE, J. B.; MABRY, H., eds. The flavonoids: advances in research. London: Chapman and Hall, 1982. p. 261-309. 
KWON, H. C.; JUNG, C. M.; SHIN, C. G.; LEE, J. K.; CHOI, S. U.; KIM, S. Y.; LEE, K. R. A new caffeoyl quinic acid from Aster scaber and the inhibitory against human immunodeficiency virus-1 (HIV-1) integrase. Chem. Pharm. Bull., v. 48, n. 11, p. 1796-1798, 2000.

MOREIRA, R. R. D., CARLOS, I. Z., VILEGAS, W. Macrophage activation by Paepalanthus spp. Extracts. Ver. Bras. Farmacog., v. 9-10, p. 37-42, 2000.

PIACENTE, S.; SANTOS, L. C.; MAHMOOD, N.; ZAMPELLI, A.; PIZZA, C.; VILEGAS, W. Naphthopyranone glycosides from Paepalanthus microphyllus. J. Nat. Prod., v. 64, p. 680-682, 2001.

SANTOS, L. C.; PIACENTE, S.; PIZZA, C.; ALBERT, K.; DACHTLER, M.; VILEGAS, W. Planifolin, a new naphthopyranone dimer and flavonoids from Paepalanthus planifolius. J. Nat. Prod., v. 64, p. 122124, 2001a.

SANTOS, L. C.; PIACENTE, S.; DE RICARDIS, F.; ELETTO, A. M.; PIZZA, C.; VILEGAS, W. Xanthones and flavonoids from Leiothrix curvifolia and Leiothrix flavescens. Phytochemistry, v. 56, p. 853-856, 2001 b.

SHIMOMURA, H.; SASHIDA, Y.; MIMAKI, Y. Bitter phenylpropanoid glycosides from Lilium speciosum var. Rubrum. Phytochemistry, v. 2, p. 2897-2899, 1986.
SHIMOMURA, H.; SASHIDA, Y.; MIMAKI, Y. New phenolic glycerol glucosides, regaloside $\mathrm{D}, \mathrm{E}$ and $\mathrm{F}$ from the bulbs of Lilium species. Tokyo Coll. Pharm., v. 43, p. 64-70, 1989.

TAVARES, D. C.; VARANDA, E. A.; ANDRADE, F. D. P.; VILEGAS, W.; TAKAHASHI, C. S. Evaluation of the genotoxic potential of the isocoumarin papepalntine in vivo and in vitro mammalian systems. J. Ethnopharmacol., v. 68, p. 115-120, 1999.

VILEGAS, W.; SANTOS, L. C.; PIACENTE, S.; PIZZA, C.; PAUW, E.; SANO, P. T. Naphthopyranone glycosides from Paepalanthus bromelioides. Phytochemistry, v. 49, p. 207-210, 1998.

VILEGAS, W.; DOKKEDAL, A. L.; RASTRELLI, L.; PIACENTE, S.; PIZZA, C. New naphthopyranone glycosides from Paepalanthus vellozioides and Paepalanthus latipes. J. Nat. Prod., v. 62, p. 746-749, 1999a.

VILEGAS, W.; NEHME, C. J.; DOKKEDAL, A. L.; RASTRELli, L.; PIACENTE, S.; PIZZA, C. Quercetagetin 7-methyl ether glycosides from Paepalanthus vellozioides and Paepalanthus latipes. Phytochemistry, v. 51, p. 403-409, 1999 b.

Recebido para publicação em 20 de novembro de 2003. Aceito para publicação em 15 de outubro de 2004. 